\section{連载}

\section{講義}

豊 田政男**

\title{
不均質材のカ学（光の 3)
}

\section{3. 異材接合体の熱応力問題}

\section{Mechanics for Heterogeneous Materials [III]}

\section{Thermal/Residual Stresses in Bonded Joints of Dissimilar Materials*}

\author{
by Masao Toyoda** \\ キーワード：異材接合体，セラミックス・金属接合，薄膜，熱応力， \\ 残留応力，熱応力の制御
}

\section{1 複合化材料の応用と熱応力問題}

材料のもつ特性・機能を最大限に利用して複合化 しようとする場合，当然ながら材料の熱的特性や力 学的特性の異なるものを接合することになる（図 1 に各種材料の熱膨張係数と縦弾性係数の関係を示 す).その複合過程において，接合面の活性化のため 熱エネルギーが加えられる場合が多く，また複合化 の目的が耐熱性向上である場合も多い，このように 異材接合体の接合過程，あるいはそれの使用時にお ける加熱や冷却によって熱応力が発生したり，残留 応力として残ったりする. 更に，最近害用・検討さ れている表面改質などを目的として生成される高機 能・高性能異材皮膜にも同じような理由によって熱 応力・残留応力が生じる。この残留応力のために接 合や膜形成が十分にできないこともある，更に，こ れらの熱応力・残留応力は少なからず界面強度や使 用中の機能に影響を与えることが指摘さている。

異材接合体に残留応力が生じることは，例えばク ラッド網などで既に知られている，最近は，金属と セラミックスの接合，更には金属などの表面に高合 金やセラミックスなどの薄膜を溶射，蒸着，イオン プレーティング, CVD, PVD 等で成形することが行

*原稿受付 平成元年 10 月 16 日

**正 員 大阪大学工学部 member, Faculty of Engineering, Osaka University
われる。

この場合，残留応力の発生原因は大きく分けて， (1)熱膨張係数と縦弾性係数の差による熱応力に起因 するもの，と

(2)薄膜形成時などで見られる表面張力，酸化物表面

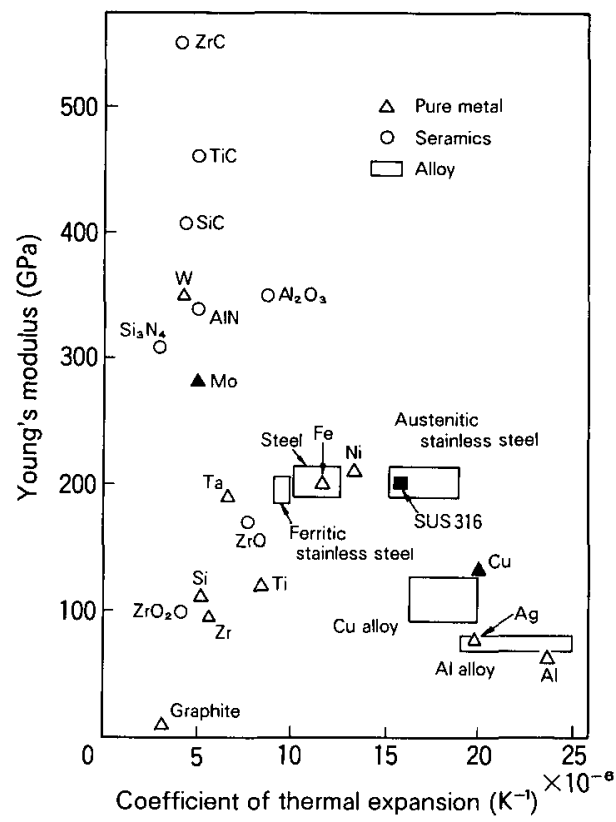

図 1 各種材料の縦弾性係数と線膨張係数の関係 ${ }^{2}$ 
層の生成, 結晶の成長と分布, 変態, 結晶構造の差 など，接合メカニズムに起因する内部固有応力, の二つに分けられる．後者の原因は薄膜などでは無 視できない場合も多いが，以下に述べる力学的な取 扱いでは，それらの原因で生じた残留応力を熱昰に 換算して取扱うことになり，その場合は前者と同じ 取り扱いとなる。

以下では，材料特性の暴なる材が接合された異材 接合体に生じる熱応力を取り上げる.

\section{2 異材接合体の熱応力の基礎}

\section{（1）熱応力解析の考文方}

物体の一部が加熱されるとその部分が膨張しよう とするが周囲の物質によってその変形が拘束される ために応力が生じる，ところが，熱膨張係数が異な る材の接合体では，例え均一に加熱されても，それ ぞれの熱膨張量の差のために同じように熱応力が生 じる.

異材接合体の熱応力解析に用いられる解法は, (1) 歪を抑える方法を用いた解析的手法 ${ }^{1-3)}$,(2)シアラグ 理論を用いた解析的手法 ${ }^{4-7)}$ ，それに(3) FEM, BEM などを用いた熱弾塑性数値解法，が主に用いられて いる。

簡単にするために，弾性解析を取り上げるが，熱 応力の解析の基本的な考方方は, 図 2 (a)に示すよう に, 加熱部の自由膨張を拘束するための応力 $\sigma_{1 j}{ }^{\prime}$ と, 加熱部周辺に $\sigma_{i j}{ }^{\prime}$ と逆符号の応力を作用させた場合 に生じる応力 $\sigma_{1 j} ”$ の和として求められる. 熱応力解 析は, この応力をいかに求めるか, 特に後者の応力 解析が問題となる。この考え方は異材の接合体で あっても同じである．図 2 (b)に異なる二材の接合体 の均一加熱の場合の解析の考え方を示す.

（2）歪を抑える方法による弾性熱応力解

異材平板の接合体，あるいは異材皮膜をもつ材の 熱応力解析は, 䄳を抑える方法を直接的に用いて解 析解が比較的簡単に求められる。特に, 板厚に比べ て十分に広い平板の場合には梁理論との組み合わせ によって, 平板の端部を除いて(この点については 後述する) 解析解が求められる。表 1 亿均質材も含 め簡単な場合の求められている熱応力解をまとめて ある1-3!

（3） シアラグ理論を用いた解法4-7)

この考え方は異材の間に剪断力のみを伝達する 層が存在するとし，力とモーメントの釣り合いから 解く方法である。この考え方はこれまでにも，隅肉 溶接により力が伝達される構造の応力解析に用いら
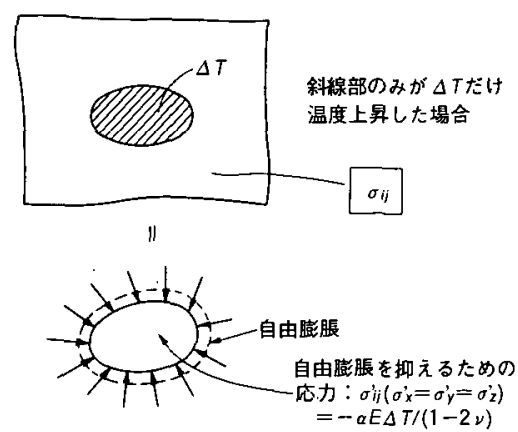

$+$

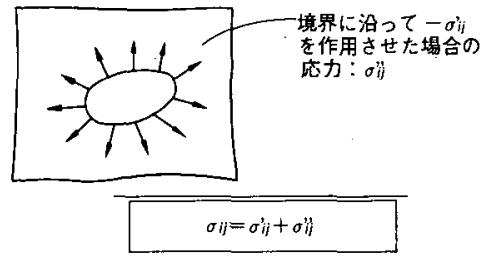

(a)
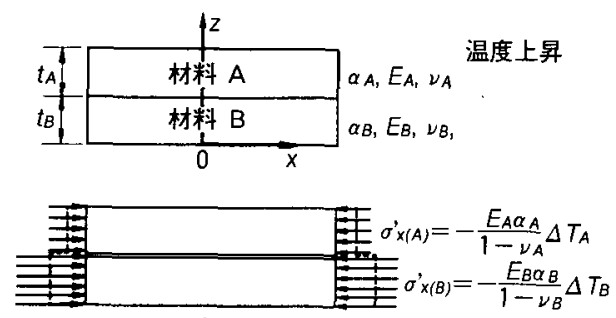

自由膨脹を抑えるための応力： $\sigma_{\text {× }}^{\prime}$

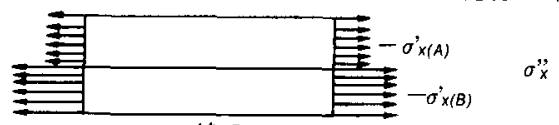

境界に一 $\sigma_{x}^{\prime}$ を作用させたときの応カ： $\sigma_{x}^{\prime \prime}$

$\sigma_{x}=\sigma_{x}^{\prime}+\sigma_{x}^{\prime \prime}$

(b)

図2 歪を抑える方法に上る熱応力解析の考え方 (a) 基本的考无方

(b)異材平板の接合体の場合の考え方

れている。これまでにも，ろう接手あるいは多層デ バイスなどで柔らかい層をもつ場合の熱応力解析に 用いられている。

異なる二材の接合部の解析で，中間層を仮定し， その厚さを零にした極限を取ると, 当然ながら表 1 に示す解と全く一致することが確かめられてい $ろ^{3}$.

(4) 数値解析と塑性問題

表 1 に示すような比較的簡単な場合は解析的に解 くことができ, 解析解は支配パラメーターを理解す るのに有効である。しかし，例えば，有限寸法の平 板の接合で端部近傍の正解を求めるのは容易でな 
表 1 均質および異材接合体の熱空力の簡単な解析例（豊田ら）

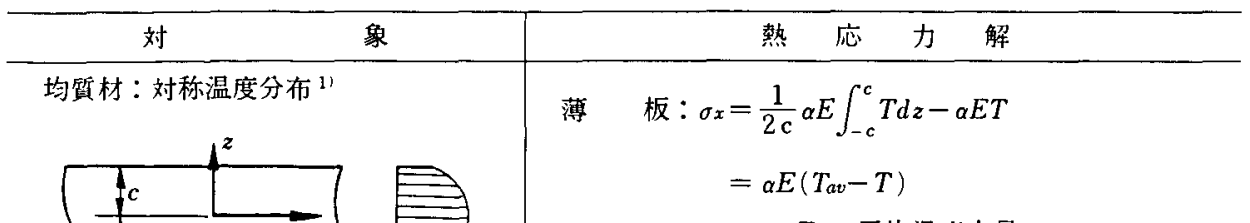

$T_{a v}:$ 平均温度上昇

無限平板 $: \sigma_{x}=\frac{\alpha E}{1-\nu}\left(T_{a v}-T\right)$

均質材：非対称温度分布 ${ }^{11}$
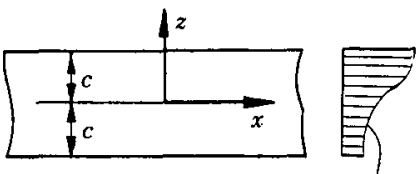

無限平板：

薄 板：

$$
\begin{aligned}
\sigma_{x} & =-\alpha E T+\alpha E T_{a v}+\frac{3 z}{2 c^{2}} \alpha E \int_{-c}^{c} T z d z \\
& =\alpha E\left(T_{a v}-T+\frac{3 z}{2 c^{2}} \int_{-c}^{c} T z d z\right)
\end{aligned}
$$

$$
\sigma_{x}=\frac{a E}{1-\nu}\left(T_{a v}-T+\frac{3 z}{2 c^{2}} \int_{-c}^{c} T z d z\right)
$$

二材接合平板：各材一様温度上昇 ${ }^{2 \nmid 31}$

$\mathrm{A}$ 材 : $\sigma_{\left.x_{i A}\right)}=\frac{E_{A}}{1-\nu_{A}}\left(\alpha_{A} \Delta T_{A}-\alpha_{B} \Delta T_{B}\right)\left(-a^{*}+c^{*} z^{*}\right)$

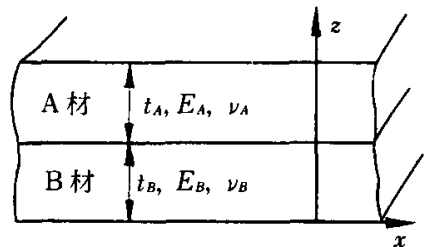

$\mathrm{B}$ 材 : $\sigma_{x(B)}=\frac{E_{B}}{1-\nu_{B}}\left(\alpha_{A} \Delta T_{A}-\alpha_{B} \Delta T_{B}\right)\left(b^{*}+c^{*} z^{*}\right)$

$$
\text { ここで } \quad a^{*}=A / D, b^{*}=B / D, c^{*}=C / D, z^{*}=z / t_{B}
$$

$A=k_{E} k_{t}\left(4 k_{t}{ }^{2}+9 k_{t}+6\right)+1$

$B=k_{E} k_{t}\left(k_{E} k_{t}^{3}-3 k_{t}-2\right)$

$C=6 k_{\varepsilon} k_{t}\left(k_{t}+1\right)$

$\left.\left.D=\left(k_{\mathrm{E}} k_{\mathrm{t}}^{2}+1\right)^{2}+4 k_{\mathrm{E}} k_{t}\right\}\left(k_{t}+1\right)^{2}-k_{t}\right\}$

$\mathrm{A}$ 材: $\Delta T_{A}, \mathrm{~B}$ 材 $: \Delta T_{B}$

$k_{E}=E_{A} / E_{B}, \quad k_{t}=t_{A} / t_{B}$

二材接合円筒：一様温度上昇 ${ }^{2}$

$\mathrm{A}$ 材: $\sigma \theta(A)=\frac{E_{A}}{1+\nu}\left(\frac{1}{a^{2}}+\frac{1}{r^{2}}\right) c_{A}$

$\mathrm{B}$ 材: $\sigma_{\theta(B)}=\frac{E_{B}}{1+\nu}\left(\frac{1}{c^{2}}+\frac{1}{r^{2}}\right) C_{B}$

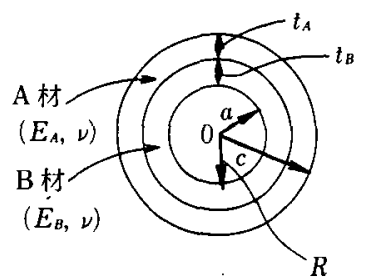

ここで

$$
\begin{aligned}
c_{A}= & A / C, \quad c_{B}=B / C \\
A= & a^{2} R^{2}\left(R^{2}-c^{2}\right) E_{B}\left(\alpha_{B}-\alpha_{A}\right) \Delta T \\
B= & c^{2} R^{2}\left(R^{2}-a^{2}\right) E_{A}\left(\alpha_{B}-\alpha_{A}\right) \Delta T \\
C= & \left\{(1-2 \nu) R^{2}+a^{2}\right\}\left(R^{2}-c^{2}\right) E_{B} \\
& -\left\{(1-2 \nu) R^{2}+c^{2}\right\}\left(R^{2}-a^{2}\right) E_{A}
\end{aligned} .
$$

温度上昇: $\Delta T$

い. そこで一般には, FEM, BEM 等の数値解法が適 用され，汎用プログラム等もあり多くの計算例が示 されている（例えば 2,8-12 など多くの例あり）. 数值計算に当たっては, 定性的議論はともかく応力 の絶対値を取り扱うときにはメッシュ分割などに十
分な注意を払う必要がある。また，塑性問題を取り 扱うときも現状では数值計算に頼ることになる。

\section{3 異材接合体の熱応力と光の支配因子}

（1）十分に大きな寸法の二つの平板の場合 表 1 に示したように，二つの無限平板の接合体の 
熱応力は界面に平行な応力成分のみで，表 1 の材料 $\mathrm{A}$ が $\Delta \mathrm{T}_{\mathrm{A}}$, 材料 $\mathrm{B}$ が $\Delta \mathrm{T}_{\mathrm{B}}$ だけ温度変化したとき, 生じる応力の大きさ $\sigma_{\mathrm{x}(\mathrm{A}, \mathrm{B})}$ は, 次のような関数形で 与えられる。

$$
\begin{aligned}
& \sigma_{\mathrm{X}(\mathrm{A}, \mathrm{B})} /\left\{\mathrm{E}_{(\mathrm{A}, \mathrm{B})} /(1-\nu(\mathrm{A}, \mathrm{B}))\right\} \\
= & \left(\alpha_{\mathrm{A}} \Delta \mathrm{T}_{\mathrm{A}}-\alpha_{\mathrm{B}} \Delta \mathrm{T}_{\mathrm{B}}\right) \times \mathrm{f}\left(\mathrm{k}_{\mathrm{E}}, \mathrm{k}_{\mathrm{t}}, z^{*}\right) \\
こ こ て ゙, & \mathrm{k}_{\mathrm{E}}=\mathrm{E}_{\mathrm{A}} / \mathrm{E}_{\mathrm{B}}, \mathrm{k}_{\mathrm{t}}=\mathrm{t}_{\mathrm{A}} / \mathrm{t}_{\mathrm{B}}, \mathrm{z}^{*}=z / \mathrm{t}_{\mathrm{B}}
\end{aligned}
$$

と表すことができ ${ }^{2-3)}$, その支配因子は(1)材料特性值 と(2)形状パラメータの二つであり，特に，
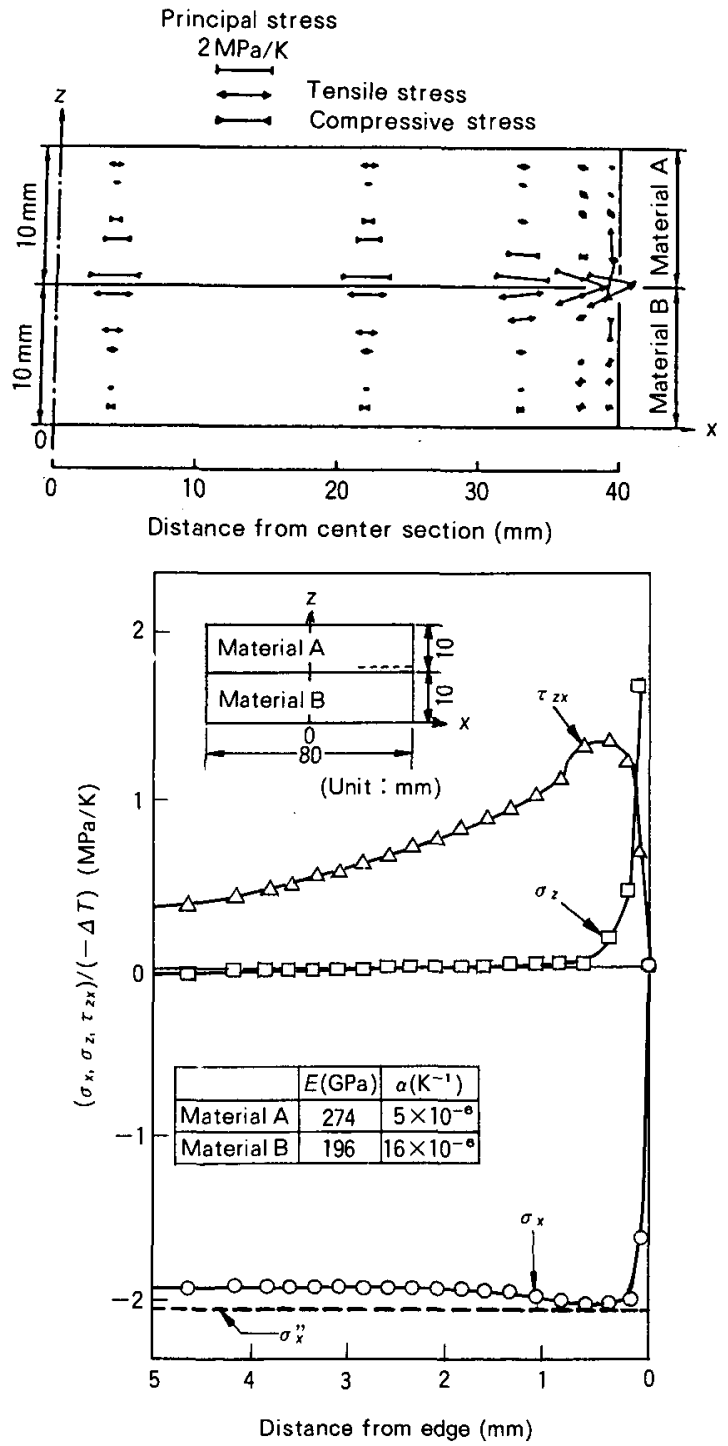

图 3 二つの異なる材料の有限寸法平板の接合体の 端部近傍の応力特性（豊田ら）

(a)主応力分布

(b)端部近傍の界面に沿う各種応力分布
(1)は，それぞれの熱歪の差，と縦弾性係数の比 $\mathrm{k}_{\mathrm{E}}$, (2)は，板厚比 $\mathrm{k}_{\mathrm{t}}$

が主要支配因子となる。

薄膜の熱応力でも，その支配因子は同じであるが， その場合寸法比は一般に小さいので，材料特性值の みに大きく依存すると考えてよい3).

（2）有限寸法平板の接合体

有限寸法の場合には, 端面の存在が大きく影響し, 端面近傍では板厚方向 ( $z$ 方向) の応力や界面に沿う 剪断応力が生じる. 図 3 に, 一例として弾性計算に おける端面近傍の主応力図と界面に沿う応力分布を 示す2).

この場合も，応力の支配因子は(1)に述べたものと 同じである 2,9$)$.しかし, 端部近傍の応力分布の形は, 材料の線膨張係数の大小に加え, 縦弾性係数の組み 合わせに大きく依存する ${ }^{2,13)}$.

\section{4 異材接合体の熱応力・残留応力}

（1）セラミックスと金属の接合体

図 1 のように，一般にセラミックスは構造用鋼材 に比べて, 縦弾性係数が同等以上, 線膨張係数は小 さい，そのため，表 1 によって計算すると，接合過 程のように一高温加冷却されるとき，接合体中央 部でセラミックスには圧縮応力が生じる。しかし， 接合体の端部近傍では, 前述のように一高温から冷 却されるとき，端部近傍のセラミックスには界面に 垂直な引張り応力が生じる。この引張り応力が，接 合過程における界面剶離やセラミックスの割れをも たらす原因となる，図 4 は図中に示す材料定数をも つ材の接合体を単位温度冷却したときの端面に沿う 板厚方向応力の分布を示したものである ${ }^{2}$ ．接合界

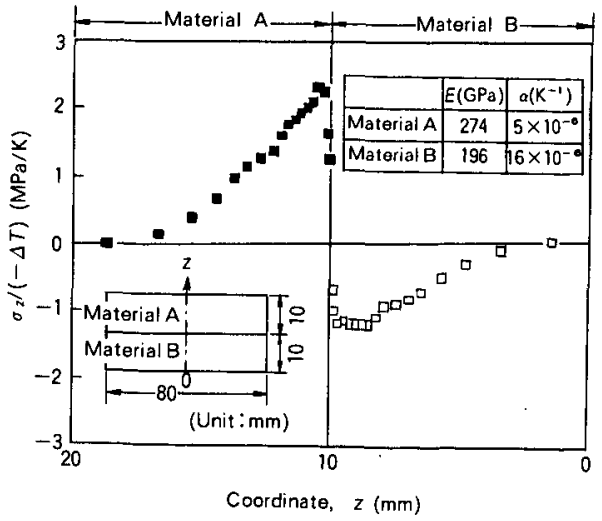

图 4 二材 $\mathrm{A}, \mathrm{B}\left(\mathrm{E}_{\mathrm{A}}>\mathrm{E}_{\mathrm{B}}, \alpha_{\mathrm{A}}<\alpha_{\mathrm{B}}\right.$ の場合) の接合体 を単位温度冷却したときの端面に沿う板厚方 向 $(z$ 方向) の応力分布特性（豊田ら） 
面端部は, 弾性的には応力の特異点となり，その近 傍の応力はかなり大きくなため，この界面端面の 処理が重要であることがうかがえる．このような観 点から, 円筒のような円周方向に端面の存在しない 接合体はこの問題が生じない2).

端面の引張り応力の大きさに及ぼす部材寸法の影 響は小さく, $\mathrm{k}_{\mathrm{E}}\left(=\mathrm{E}_{\mathrm{A}} / \mathrm{E}_{\mathrm{B}}\right)$ の影響が大きい. $\mathrm{k}_{\mathrm{E}}$ が小 さいほど引張り応力は小さくなるが，一般にセラ ミックスと鋼材の組み合わせでは $\mathrm{k}_{\mathrm{E}}>1$ となり，応 力を小さくすることは難しい22.

(2) 溶射皮膜の残留応力

溶射皮膜の残留応力はセラミックス系か金属系か によって傾向が異なる，金属系では，一般にかなり 大きな引張り残留応力（材料の降伏点に近い值）が 残る。それに対してセラミックス系では多くの場合 計測される残留応力は見かけ上小さい場合が多 い ${ }^{14)}$.これは溶射皮膜に冷却中に既にミクロな割れ が生じていること，また溶滴粒子間の結合力が小さ いとかボイドが生じて変形し易くて, 熱膨張差を吸 収するためである。

(3) 薄膜内の残留応力とその測定

蒸着や PVD, CVDなどで形成される $1 \mu \mathrm{m}$ 以下 程度の薄膜内の残留応力の剆定は必ずしも容易でな い. 代表的な測定法としては，X 線回折法とたわみ 法がある. 後者を用いる場合, 基板の材料特性の影 響を正確に考慮するとともに，皮膜の材料特性の正 確な把握が重要である.

図 5 は各種金属の蒸着膜の残留応力と膜厚の関係 の実測例である ${ }^{15)}$. 膜厚が小さい範囲では, 膜を形成 するに至らず応力の值も小さいが，数十 $\mathrm{nm} に も な ~$ ると膜としての特性を示すと言える。

このような蒸着膜では, 膜だけを取り出しても残 留応力が残っている。これは非情に薄い膜の内部で 結晶組織などの異なる層が形成されていくためで, 薄膜内の残留応力の解析には，この点を考えた膜内 の不均質性に注目し, 膜内の一部に固有昰が存在す るとして, 表 1 に示す弾性解析を用いる方法が提案 されている (図6に解析の考え方を示す) ${ }^{16)}$.

\section{5 熱応力の制御に対する塾み}

材料の線膨張係数が著しく異なる材料の接合体で は, 加熱・冷却過程で生じる熱応力の発生は避け難 く，その值もかなり大きい. そのために接合過程で 剝離したり割れたりするとともに，接合体の残留応 力は接合界面強度を低下させることになる。この熱 応力・残留応力の緩和の手法がいろいろと検討され

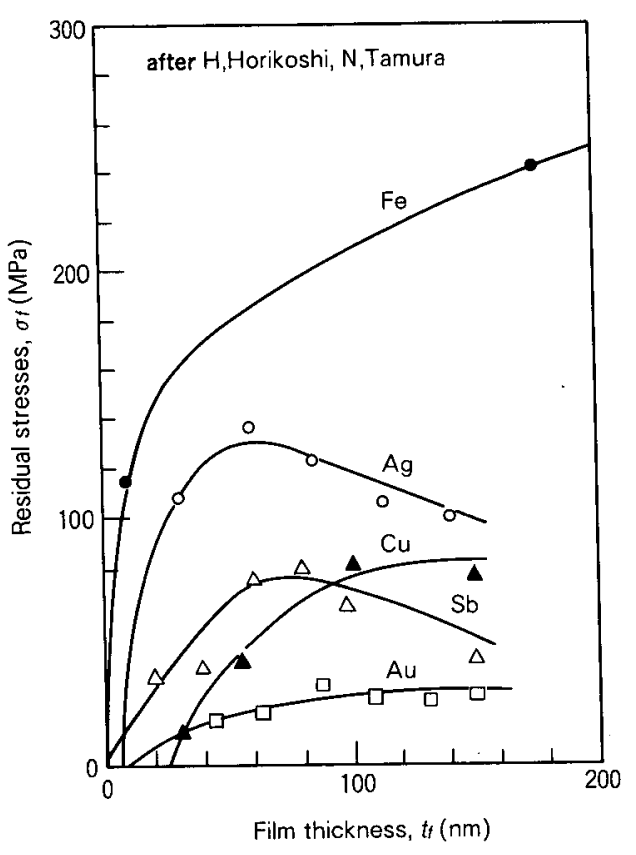

図 5 金属蒸着膜の残留応力と膜厚の関係(堀越ら)

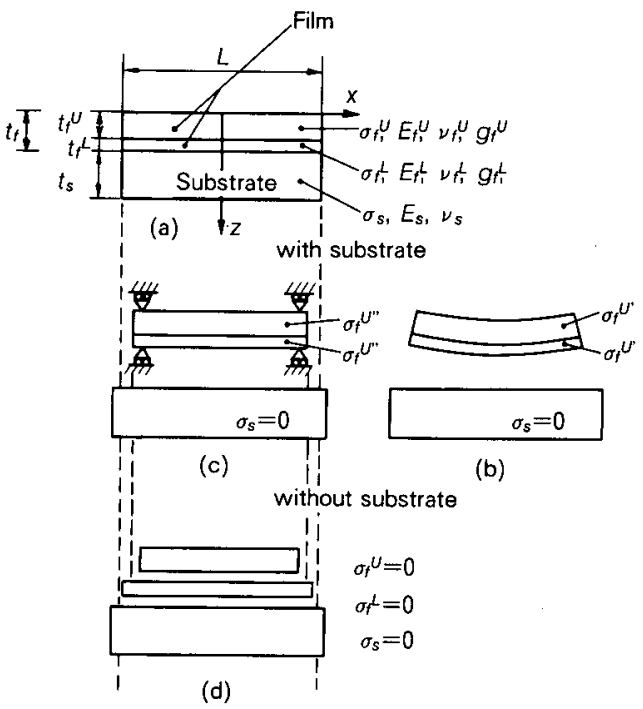

図 6 薄膜の固有残留応力を評価するための固有歪 を導入した弾性解析の考え方 (豊田ら). (薄 膜を二層に分け ((a)図)，膜生成過程で生じる 固有応力をそれぞれの層の固有歪に置き換え る、したがって，膜のみをはくりすると(b)図 のように変形する。ここでの解析では同時に 膜内の縦弾性係数の差も考慮する) 


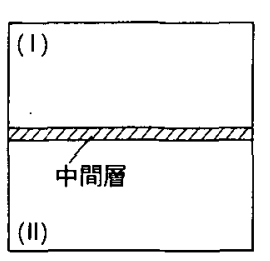

中間層の種類 :

一延性に富んだ金属箔

(低降伏点)，(Ni, Alなど)

一金属・セラミックス混合粉体

一アモルファス材料

一相変態ひずみの利用

一エピタキシャル界面の利用 など

(II)：セラミックス・高融点金属など（I）：一般構造用金属

(a) 中間層を用いる方法
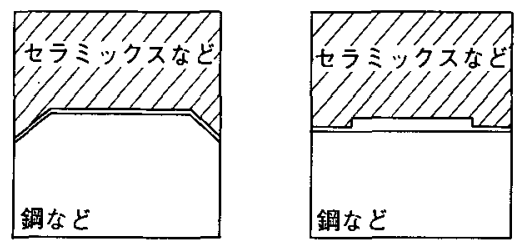

（b）接合界面形状の制御

图 7 異材接合体の残留応力緩和手法の代表例

ている. 図 7 に現在用いられている制御手法の代表 的なものを示す.中間層を用いる材料特性の制御と， 接合部の形状を工夫して界面端部の応力を制御する 手法がある．中間層を用いて熱応力を緩和する手法 は, 中間層の変形によって異材間の熱歪差を吸収し ようとするものである，その原理から考えて，用い る中間層は変形能に富んでいることが必要で，特に 中間層が薄い場合には，中間層の熱膨張係数を制御 する手法は有効ではない．中間層がある程度の厚さ を確保できるときに注，傾斜特性材料を用いるのも 一方法である。

蒸着膜のような場合には，膜と基板の材料特性の 差のみならず, 薄膜の成長過程で発生する固有応力
（真性応力とも呼ばれる）が重要で，その緩和のた めに, 基板の加熱, 不純物ドーピング，イオン衝撃 などを用いたり，膜形成後にアニーリングしたりイ オンプランテーションするなどで緩和する方法があ る.

異材接合体に生じる熱応力の制御は，高機能複合 化材料の生成にとって久くことのできないものであ る.そのためには熱応力の支配因子を明確にするこ とと, 特に, 定量的評価が重要である. 残留応力の 生成原因の解析とともに, 適切な力学的評価手法の 選択に注意すべきである。

\section{参 考 文 献}

1) Timoshenko, T. and Goodier, J. N., Theory of Elasiticity, McGraw Hill, (1970), 433

2) Toyoda, M., et al., IIW Doc. X-1161-88, (1988)

3）豊田，吹田，外，溶接学会論文集，7 (1989)，543

4) Chen, W. T. and Nelson, C. W., IBM J. Res. Dev., 23 (1979), 179

5) Ishai, O. and Gali, S., J. Adhesion, 8 (1977), 301

6) Chen, D., Cheng, S. and Gerhardt, T. D., J. Thermal Stresses, 5 (1982), 67

7) 渡辺, 日本航空宇宙学会誌, 30 (1982), 535

8）菅沼，岡本，日本溶射協会誌，22 (1985), 929

9）寺崎, 外, 溶接学会論文集, 5 (1987), 103

10) 瀬尾, 外, 日本機械学会関西支部講演会, (1988)

11) 河野, 日置, 外, 溶接学会論文集, 3 (1985), 1-104

12) 浜田, 暮石, 外, 溶接学会論文集, 3 (1985), 3-47

13）漌口，小林，外，神戸製鋼技報，39 (1988)，77

14）納富, 外, 溶接学会論文集, 6 (1988), 341

15）堀越，田村，真空，第 6 巻，第 5 号， 182

16) 豊田, 吹田, 外, 溶接学会構造研究委員会資料 (1989), 7 月 